\title{
Correction
}

\section{Cardiomyopathy Caused by Longterm Treatment with Chloroquine: A Rare Disease or a Rare Diagnosis?}

E. Tönnesmann, I. Stroehmann, R. Kandolf, H.Wolburg, K. Strach, F. Musshoff, K. Tiemann, T. Lewalter.

Cardiomyopathy caused by longterm treatment with chloroquine: A rare disease or a rare diagnosis? J Rheumatol 2012;39:1099-1104. In Table 1 of the online version of this report, for the authors Roos, Freihage, and Nord, listed in Column 1, the entries intended for Column 10 under "Histology" are misaligned. The entries should read: "A/A/EMB" for Roos, "EMB" for Friehage, and "A" for Nord. The author listing in Column 1 "Jimenez" should read "Hernandez-Jimenez". A corrected pdf of this report is available from the online table of contents. To view/download the corrected version visit jrheum.org and follow the prompts to Volume 39, No. 5.

doi:10.3899/jrheum.110959.C1 